\title{
A Golden Spike ürhajózási magánvállalat
}

\section{Az ALAPÍtók}

A Golden Spike vállalatot Dr. Alan Stern alapította, aki 2007 és 2008 között a NASA tudományos tanácsadója volt. Cégalapító társa, Gerald Griffin, a NASA Johnson Ürközpontjának korábbi igazgatója. A vállalat vezetői közé tartozik továbbá Esther Dyson ürkutató és Taber Mac Callum, a Paragon Ürrejlesztési Társaság vezérigazgató-társalapítója. A tanácsadók között megtalálható Newt Gongrich, az amerikai képviselőház korábbi elnöke, Wayne Hale, a NASA Ürrepülőgépes programjának egykori igazgatója, továbbá Bill Richardson szakíró és repüléstechnikai mérnök, Új-Mexikó hajdani kormányzója. A vállalat a nevét arról a különleges aranyszögecsről kölcsönözte, amelyet az első transzkontinentális vasútvonal végső munkálata alkalmából rögzítettek a sínekbe, s tették lehetővé ezáltal a vasúti összeköttetést a keleti és a nyugati part között.

\section{TÖRTÉNELLI VISSZATEKINTÉS}

A vállalat, és a hozzá kapcsolódó személyek első említése egy 2012. május 12-én, Hawaii-on lezajlott konferenciához köthető, ahol elhangzott a már ismert, Golden Spike elnevezés, összefüggésben egy magánkezdeményezéssel, amely elismert tudósok és űrhajózási szervezetek összefogásával jött létre, célja pedig megbízható, a „Holdig vezető szupersztráda” kifejlesztése és létrehozása. A Golden Spike hivatalosan 2012. december 6-án lépett a nyilvánosság elé egy sajtókonferencia keretében, akkor mutatkozott be a cégvezető, valamint számos munkatárs, akik ismertették a vállalat programját is.

Az utolsó ember, aki a Holdon sétált, az Egyesült Államok űrhajósa, Eugene Cernan, az Apolló-17 parancsnoka volt, aki a 2012-es sajtókonferenciához képest - néhány nap eltéréssel - 40 évvel korábban indult a világürbe a Kennedy Ürközpontból, s habár azóta számos űrprogram keretében kapott helyet a Hold kutatása, ember mégsem tette a lábát a felszínére. A Golden Spike ezen a helyzeten szeretne változtatni, szeretné összefogni egyúttal a különböző országokban működő, hasonló célú állami és magánszervezeteket, elősegítve a Holdra való visszatérést.

\section{TERVEK ÉS ANYAGI FORRÁSOK}

2012 decemberében a vállalat elnök-vezérigazgatója, Dr. Alan Stern beszámolt arról, hogy a Golden Spike megalapításának ötlete évekkel korábbra nyúlik vissza, hiszen már 2010 elején is készítettek tanulmányokat magánfinanszírozású holdrepülésekről. A vállalkozást hivatalos formában azonban csak az év harmadik negyedévében hozták létre. Attól az időtől kezdve a vállalat folyamatosan építi üzleti kapcsolatait és végzi beruházásait. A cég - tervei szerint - éves szinten szeretné elérni a 7-8 milliárd dolláros költségvetést, céljaik eléréséhez ennyit tartanak szükségesnek. Egy-egy kétszemélyes holdrepülés árát 1,5 milliárd dollárban jelölik meg. A Golden Spike fejlesztési logikája az orosz űripar 1980-as és 1990-es években folytatott mintáját követi. A cég álláspontja szerint a költségeket alacsony szinten tudják tartani más űrkutatással foglalkozó vállalatokkal történő együttműködés révén, a már létező, vagy megvalósítás alatt álló hordozórakéták felhasználásával, az ő számukra csupán a holdra szálló egység megépítése, valamint az űrhajósoknak a holdfelszíni tevékenység végzéséhez kifejlesztendő speciális ürruha megalkotása marad. Dr. Stern bízik abban, hogy legalább 15-20 ország ürkutatási szervezete csatlakozik elképzeléséhez, várja továbbá nagyvállalatok és olyan személyek jelentkezését is, akik tudományos célokból kívánnak eljutni a Holdra. A vállalat tudósai már kidolgozták a holdküldetés repülési profilját különböző felbocsátási megoldásokat figyelembe vége, meghatározták a pontos pályaadatokat, és megtervezték a leszállóegység felszínre jutásának részleteit. Kétszer két indítással számolnak a Földről a földkörüli pályára. Az egyik páros a holdra szálló egységet és a Hold felé vezető hajtóművét (LTV) viszi fel, a másik pedig a legénységi űrhajót, és annak Holdhoz szállítását végző rakétafokozatát (LTV). A két gyorsító-egységet később leválasztják. A holdkörüli pályán a leszállóegység és a legénységet szállító űrhajó összekapcsolódik, a legénység átköltözik a holdkompba. A program végeztével visszatérnek a holdkomppal, átszállnak az űrhajóba és a Föld felé veszik az irányt.

A Golden Spike által használt űrhajót és annak valamennyi berendezését amerikai vállalatok gyártják majd. Az első repülésre már 2020-ban sor kerülhet (a cég szerint - Szerk.).
ÖSSZEFOGLALÁS: Az utóbbi időben a magánvállalatok egyre nagyobb szerephez jutnak az ürkutatásban, egyre ambiciózusabb célokat tüznek ki maguk elé. A Golden Spike vállalat székhelye az Egyesült Államok Colorado Államában található. Nem kevesebbre vállalkoznak, mint magánürhajók indítására a Hold felszínére. A Golden Spike vállalatot érintő, az elmúlt hónapokban történt legfontosabb események közé tartozik a Holdtudományi Tanácsadó Testület megalapítása.

KULCSSZAVAK: ürkutatás, magán ürhajózási cégek, Golden Spike vállalat, Holdtudományi Tanácsadó Testület
ABSTRACT: Recently, private companies bear an ever-increasing part in space exploration, they set more and more ambitious aims for themselves. The head office of the company is found in Colorado, in the United States. The aspiring task they undertook is to launch private spaceships to the surface of the Moon. In the months past, one of the most important events related to the Golden Spike Company was formation of the Lunar Space Advisory Board.

KEY WORDS: space exploration, private space companies, Golden Spike Company, Lunar Space Advisory Board 


\section{Golden Spike Mission Stages}

The lander, crew vehicle and LTV are all launched separately. The plan requires rendezvous of elements in Earth orbit and moon orbit, as well as refueling of the LTV

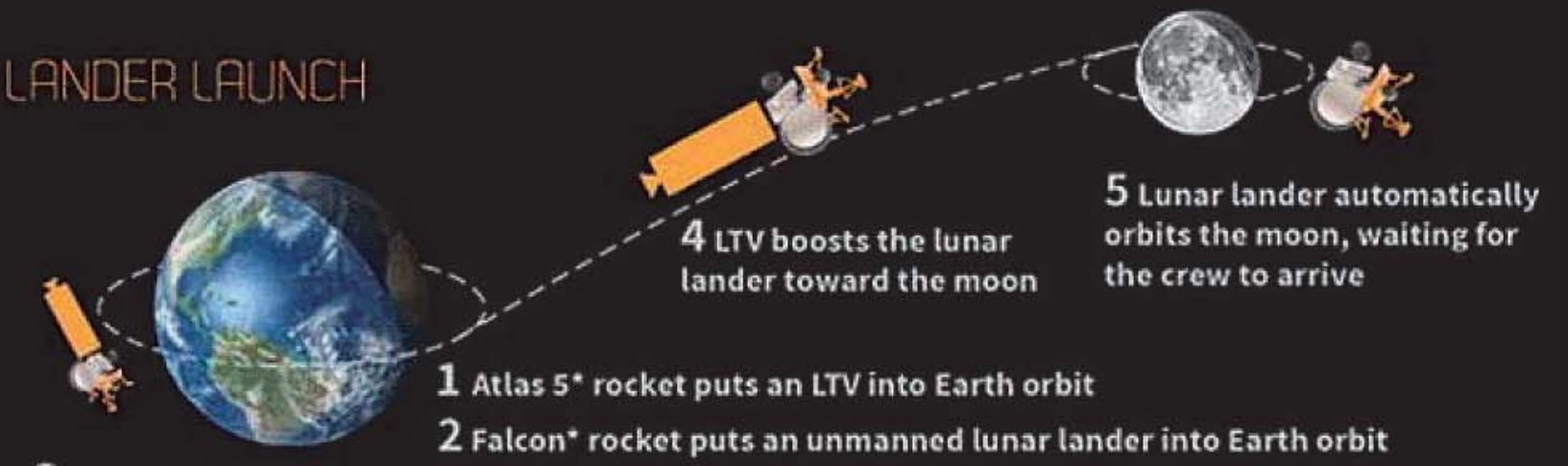

3 Refucled LTV links up with lander in Earth orbit

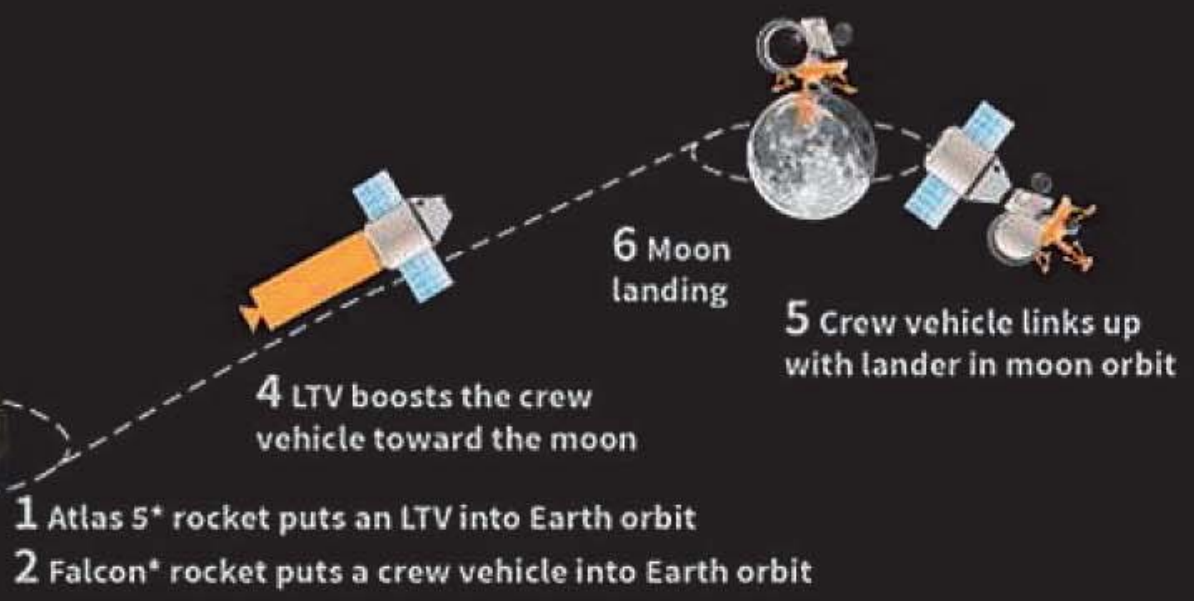

3 Refueled LTV links up with crew vehicle in Earth orbit

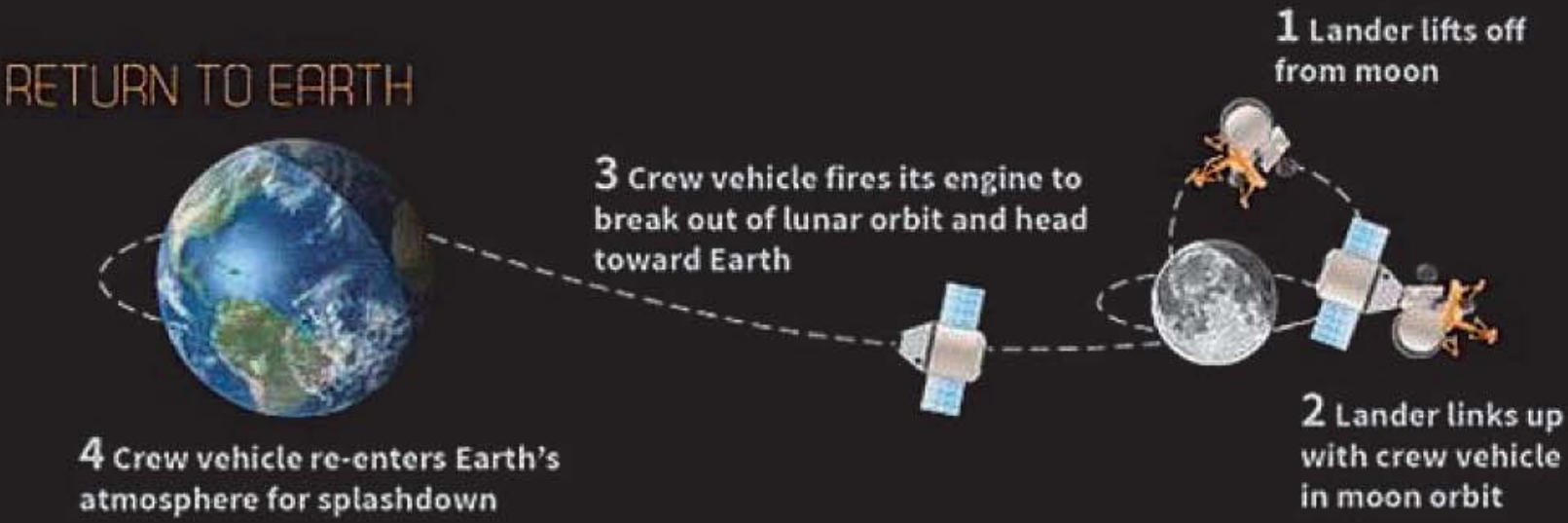

\section{"Examples only; final hardware not selected}

1. ábra. A Golden Spike által tervezett holdra szállás három fázisa. (Az ábrán jelölt hordozórakéták változhatnak.) I. fázis. A leszállóegység felbocsátása. Föbb lépések: 1 . Az Atlas-V rakéta felviszi föld körüli pályára a holdkompot a Holdhoz szállító rakétafokozatot (LTV). 2. Egy Falcon rakéta felviszi magát a holdkompot. 3. A két egység föld körüli pályán összekapcsolódik. 4. Elindulnak a Hold felé. 5. A Holdkomp pályára áll a Hold körül. II. fázis. A személyzet felbocsátása. 1. Az Az Atlas-V rakéta felviszi föld körüli pályára a személyszálító úrhajót a Holdhoz szállító rakétafokozatot (LRV). 2. Egy Falcon rakéta felviszi föld körüli pályára a személyzetet szállító űrhajót. 3. A két berendezés föld körüli pályán összekapcsolódik. 4. Az LTV hold körüli pályára viszi az ürhajót. 5. Az ürhajó és a már Hold körül keringő holdkomp összekapcsolódik. 6. A legénység átszáll a holdkompba és végrehajtja a holdra szállást. Ill. fázis. Visszatérés a Földre. 1. A holdkomp felszáll a Holdról. 2. Összekapcsolódik a Hold körül keringő ürhajóval. 3. A legénység átszáll az ürhajóba, beindítja a hajtómúveket és a Föld felé veszi az irányt. 4. Az űrhajó belép a Föld légkörébe, majd az ürkabinnal az óceánra ereszkedik. 


\section{SzerződÉs a Northorp Grummannal}

2013 januárjában a Golden Spike szerződést kötött a Northrop Gruman Vállalattal - a holdkomp megtervezése és megépítése lesz a feladatuk. A kereskedelmi holdtevékenység megindítása terén tehát a legfontosabb elem elkészítését helyezik előtérbe. A szerződés a „követelmények felülvizsgálatát és összehangolását, földi szervezési és irányítási feladatok elvégzésére irányuló tanulmányok kidolgozását, rendszer-megbízhatósági követelmények teljesítéséhez vezető út kidolgozását, automatikus és/vagy parancsvezérelt üzemeltetés lehetőségét, megfizethetőségi elemzések elvégzését, a pontos sebesség-paraméterek meghatározását alacsony holdkörüli pálya elérésére, megfelelő leszállóhelyek kiválasztását, különböző koncepciókon alapuló holdkompok tervezését, továbbá a szükséges rakétafokozatokat és -hajtóműveket - biztosítván az újrahasznosíthatóságot -, autonóm rendszerek megalkotását, a kutatások támogatására szolgáló háttér megteremtését, a leszállási hely módosíthatóságát, a világűr kereskedelmi hasznosítási menetének kidolgozását, valamint a jövőben esetleg fellépő gátló tényezők elemzését, ezek legyőzéséhez szükséges elemzési és fejlesztési munkákat" foglalja magában.

Azóta nyilvánosságra került mindazon vállalatok listája, amelyek a holdraszálló egység (LLS) megépítésének érdekében csatlakoztak a kezdeményezéshez. Ezek a következők: Armadillo Aerospace, International Lunar Observatory Association, Masten Space Systems, Moon Express, Paragon Space Development Corp, Southwest Research Institute, Space Florida, United Launch Alliance és a Zero Point Frontiers Corp.

A Golden Spike a Northrop Grummant bízta meg a leszállóegység megépítésével, de a fenti vállalatok sem maradnak munka nélkül, különböző berendezések, mint pl. a lakóegységek és a felszíni kiszolgáló létesítmények megépítése vár rájuk.

A Gerry Griffin testületi elnök és Dr. Alan Stern elnökvezérigazgató által vezetett Golden Spike - technikai értelemben - kezdő vállalat, nem áll mögötte semmilyen anyagi fedezet, üzleti modelljük felépítése nyomán keletkező, főleg a Holdra vágyó magánszemélyektől származó árbevételből kívánják finanszírozni a jövőbeli űrrepüléseket.

Mindamellett úgy tűnik, a Northrop Grumman már ebben a korai stádiumban hajlandó különböző áttekintő és megvalósíthatósági tervek készítésével előremozdítani a törekvéseket, mindeközben jelezni a nyilvánosság felé, hogy a

2. ábra. A hold-transzfer rakétafokozat pályára álítja a Hold körül a legénységet szállító ürhajót

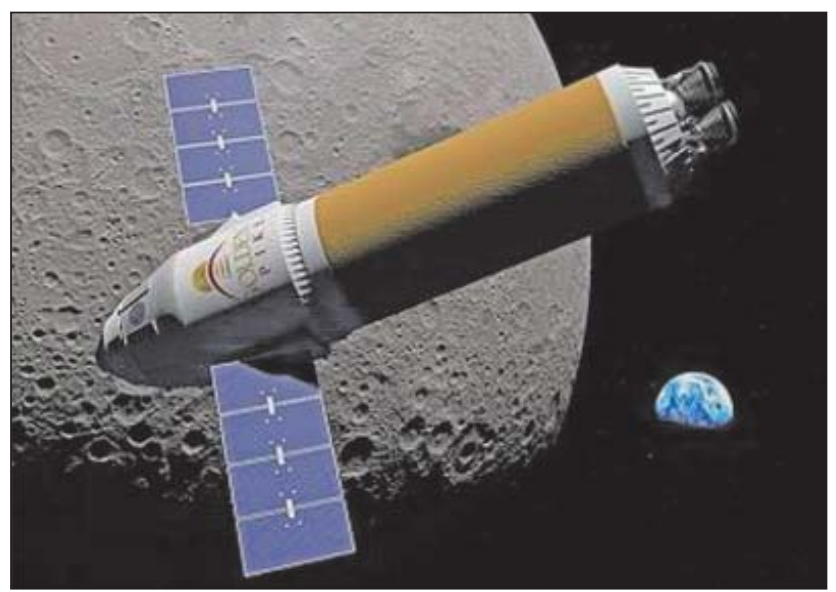

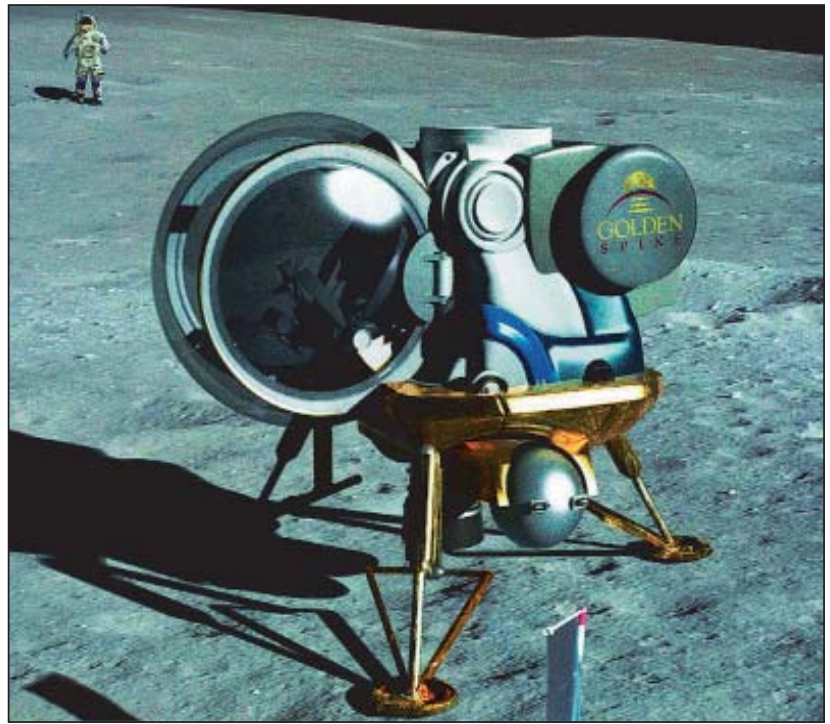

3. ábra. A Golden Spike „sportos” jellegű holdkompja

tervek és a szándékok az ember visszatérésére a Holdra, még ebben az évtizedben megvalósíthatók.

A leszállóegység rendszerének tervezésével kapcsolatban James R. French, a Golden Spike főmérnöke a következőket nyilatkozta: „A jelenlegi elképzelések csupán a kezdetet jelentik, egyelőre a tervezési követelmények meghatározásánál tartunk, most következnek majd a rendszerspecifikációk, és a szerződéskötéseket megelőző tanulmányok elkészítése. Mindezek a lépések megelőzik a holdra szálló egység kifejlesztésének és megépítésének fázisát."

A Northrop Grumman örököse a Grumman and TRW vállalatnak. Ők tervezték a holdkompot és a holdkomp leszálló-hajtóműveit az Apolló holdprogram keretében. 1969 és 1972 között hat alkalommal szállítottak az említett berendezések űrhajósokat a holdkörüli pályáról a Hold felszínére, majd újra vissza holdkörüli pályára.

Gerry Griffin a következőképpen kommentálta a szerződéskötés tényét: „Jelentős lépés terveink előrehaladását tekintve. A Northrop különleges tudása és szakmai hozzáértése garanciát jelent a Golden Spike számára, az egyetlen társaság ugyanis, amely a gyakorlatban is működőképes holdraszálló egységet tervezett az Apolló-holdprogram keretében."

A kereskedelmi tanulmány elkészítésére nem szabtak határidőt, a Golden Spike a jelen helyzetet a megvalósulás „A" fázisának tekinti. A Northrop Grumman követi ezt az iránymutatást, ugyancsak végeznek kereskedelmi jellegű tanulmányokat, saját munkájukban is ütemet szabnak a jövőben elkészítendő részletes elemzéseknek és fejlesztési munkáknak.

„Büszkék vagyunk, hogy a Northrop Grummannal dolgozhatunk - tette hozzá Dr. Stern -, a világon ők rendelkeznek a legtöbb tapasztalattal arról, hogy miként kell holdra száló egységet tervezni és építeni."

„Ami a NASA-t illeti, a Constellation Program (CxP) törlésekor lemondtak a hold felszínére való visszatérésről is. E lépés felgyorsította a Golden Spike terveinek megvalósítását". Erről ugyancsak Dr. Stern tett említést.

A NASA azonban mégis folytat kutatásokat a Hold felszínének elérését illetően, abban bízva, hogy egyszer visszatérhetnek az eredeti tervek megvalósításához, ám az ő elképzeléseik - nem utolsósorban a tervezett holdra szálló egység tekintetében is - teljes egészében különböznek a Golden Spike által felvázolt elképzelésektől. 


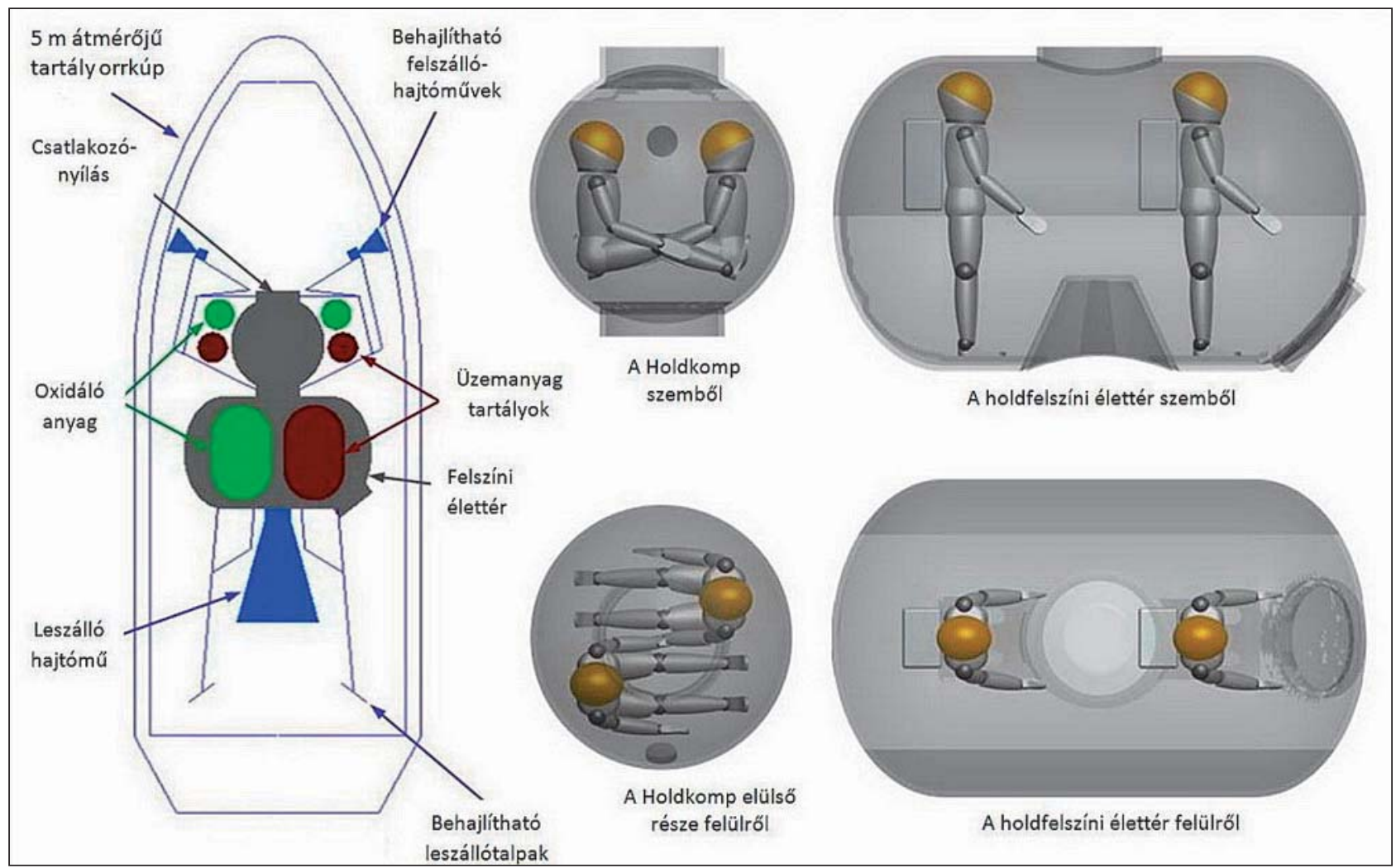

4. ábra. A Golden Spike holdkompjának elhelyezkedése a hordozórakéta orrkúpja alatt, valamint különböző szerkezeti rajzok

A NASA részéről megvan a lehetőség a Holdra való viszszatérésre, az ESD betűszóval jelzett koncepció kapcsán a földközeli kisbolygók meglátogatási célpontjai között a Hold is szerepel, az LSS (,Kiruccanás” a Holdra) küldetés keretében, amely során egyetlen alkalommal négy fő szállna le az égi kísérőnk felszínére, majd térne vissza a Földre az egyenlítői vagy a sarki térségben.

A Golden Spike álláspontja szerint a Holdra való visszatérés kulcseleme a megbízható holdra szálló egység. A NASA saját berendezése indításához az SLS óriás rakétája szükséges, a Golden Spike kisebb méretű holdra szálló egységének indításához már a SpaceX nehézrakétája is alkalmas.

A NASA holdra szálló egységének feladata lenne személyzet szálítása a Hold felszínére és onnan vissza, rövid tartózkodási időt biztosítva a legénység számára. Két fő egység alkotja, a leszálló- (DM) és a felszállóegység (AM). Az AM tartalmazza a dokkolóegységet, valamint egy átjárót a leszállóegység fedélzetére. A személyzet felszerelései, életfenntartó rendszere az AM-ben található. Létezik elképzelés három összetevőből álló holdra szálló egységre is, hosszabb idejű tartózkodást biztosító háttérrel.

Nem ismert, hogy a NASA meglebegtetett terve a Constellation Program keretében tervezett Altair leszállóegységet, vagy a különböző alapítványok által az említett leszállóegység változatain dolgozó valamelyik elképzelést részesíti-e majd előnyben. Az is elképzelhető, hogy az űrhatóság lemarad a versenytársakkal szemben.

\section{EgyütTMÜKödÉs a Draper LaBoratóriummaL}

2014 januárjában a Golden Spike Vállalatnak újabb jelentős támogatót sikerült maga mellé állítania. Az együttműködéstől a végcél megvalósulásának felgyorsulását várják.
A bejelentés idején a Golden Spike már számos, és igen fajsúlyos társaságot tudhatott maga mögött a fő cél megvalósítása érdekében: újra űrhajósokat juttatni a Hold felszínére - ám ezúttal kereskedelmi vállalkozásként.

2014 elején az elképzelések még korai fázisban jártak; a műszaki berendezések tervezésénél tartottak, a jövőbeni vásárlók és felhasználók csatlakozása - akiktől aztán a dollármilliárdok befektetését várják - még várat magukra. A Golden Spike szeretné, ha az első kísérleti repülésre már 2017-ben sor kerülhetne, amit aztán 2020-tól a tényleges kereskedelmi célú küldetések végrehajtása követhetne.

A Draper Laboratóriummal kötött együttmüködési megállapodás talán ezen is segíthet, néhány potenciális felhasználó is képbe kerülhet, miközben a Golden Spike felvonultat maga mellett néhány ismert és elismert űrkutatási vállalatot, ami hitelesíti terveik komolyságát.

A Draper Laboratórium jól ismert, megbízható partner, amely szoros kapcsolatban áll az űrrepülőgépes flottával, illetve a nemzetközi űrállomással.

A legnagyobb elismerést új metódus kidolgozásával nyerték, amellyel a nemzetközi ürállomás keringési pályáját hajtómű használata nélkül is képesek megváltoztatni, sokkal biztonságosabbá téve az űrállomás pályán tartását. Ez egyben takarékoskodást jelent a hajtóanyaggal, amivel nem utolsó sorban a NASA-nak is tekintélyes összeget spórolnak meg.

Mielőtt a Draper szakértői megjelentek volna a helyszínen az elképzeléseikkel, amelyek lényege vezérlési parancsok sorozatának kiadása az ISS manőverező-irányítási giroszkópja (CMG) által, a hasonló pályaváltoztatási manőverek egyenként egymillió dollárba kerültek.

A társaságnak a Sierra Nevada Corporationnal (SNC) közös vállalkozásban is érdekeltsége van a Dream Chaser űrrepülőgép munkálataiban, elsősorban az ISS megközelítéséhez szükséges paraméterek kidolgozásának területén. 


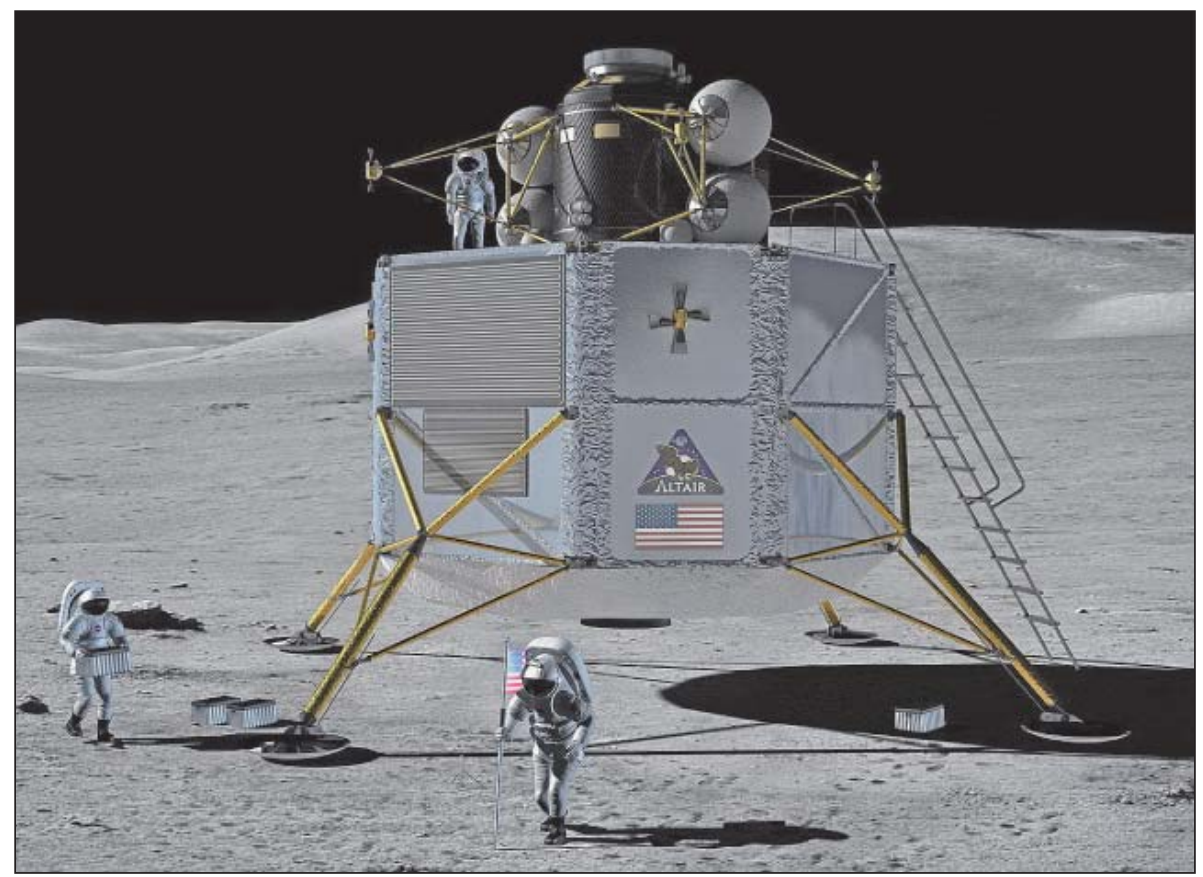

5. ábra. A NASA Altair holdkompjának legfrissebb változata

A Draper Laboratórium gyakran felbukkan az ürrepülőgépes küldetésekről szóló dokumentum-gyűjteményben (FRR), az egyes repülésekre vonatkozó részvételük kapcsán. Ez alapján tudhatjuk, hogy 133 űrrepülőgépes vállalkozásban vettek aktívan részt.

Jelen feladatuk a holdra szállások lehetséges helyszíneinek kijelölése a Golden Spike által szervezett küldetésekben.

Csúcstechnikát képviselő Tájékozódási, Navigációs- és Vezérlőrendszerük (GN\&C) nagy teljesítményű, megbízható, űrtudományos és adatfeldolgozó berendezés. A vállalat hasonlóval szolgált a Constellation Program számára, abban az időben, amikor a NASA a Holdra való visszatérést, mint közbülső lépést fontolgatta a Marshoz vezető úton.

A fejlesztések gyökerei ugyancsak az Apolló-korszakig nyúlnak vissza.

„A Draper szállította az GNC-t és a repülésirányító számítógépeket valamennyi pilótás holdraszálláshoz. Izgatottan várjuk, hogy szakértelmünkkel a Golden Spike nagyratörő terveit támogassuk, ezáltal ismét megnyíljon az út a Hold felé" - nyilatkozta a csatlakozás kapcsán John West, tudományos vezető.

Körülbelül hat hónapot vesz igénybe, amíg a Draper elvégzi a kompatibilitási kalkulációkat a Golden Spike holdra szálló egységéhez igazodva, meghatározzák a biztonságos leszállás feltételeit, a megfelelő fényviszonyokat, a leszállás pontos módját, a keringési időszak paramétereit, az Atlas-V rakéta képességei ugyanis behatárolják a Hold innenső oldalán a lehetséges leszállási helyszíneket.

Az elkészítendő tanulmány igyekszik majd feltárni a Golden Spike leszállóegysége fejlesztésében rejlő további lehetőségeket, tágítani a leszálláskor szóba jöhető területek nagyságát, továbbá azon szerkezetek meghatározását is, amelyek a továbbiakban segítenek majd a Golden Spike által végrehajtott leszállások vezérlésében, a berendezések által használt algoritmusok kidolgozásában, és az elektronikai háttér felépítésében. Rendkívül összetett és bonyolult feladat tehát.

A leszállási helyszínek elsősorban a vevők igényeitől függnek. A Golden Spike a Hold innenső oldalán a lehetőségek széles skáláiát szeretné felkínálni.
A vállalat számításai szerint a 2020-2030-as időszakban 15-25 vevő jelentkezik náluk. „Büszkék vagyunk, hogy a Draperrel dolgozhatunk, ők jelentik a legmagasabb színvonalat a leszállási helyszínek kijelölésében az Apolló-korszaktól napjainkig" - tette hozzá Dr. Stern.

\section{LEGFRISSEBB HÍREK}

A Golden Spike vállalatot érintő, az elmúlt hónapokban történt legfontosabb események közé tartozik a Holdtudományi Tanácsadó Testület (LSAB) megalapítása, a hold- és bolygótudományok terén jelentős eredményeket felmutató tudósok részvételével.

Az LSAB tudományos tapasztalatokkal szolgál a Golden Spike részére, valamint stratégiai útmutatásokkal nyújt támogatást a végrehajtandó kutatómunkával kapcsolatban, továbbá a mintavételi eljárásokkal és a felszínen végrehajtott kísérletekhez szükséges berendezések használatával összefüggésben.

Bejelentés hangzott el a Honeybee Robotics csatlakozásáról is, e vállalat vezető szerepet tölt be a világür robotokkal történő felderítésében. Első megbízásuk alapján automata holdjárók segítségével kell előkészíteniük a pilótás repüléseket.

\section{FORRÁSOK}

space.com;

http://www.nasaspaceflight.com/2013/01/golden-spikenorthrop-grumman-lunar-lander/;

http://www.nasaspaceflight.com/2013/10/golden-spikelunar-sample-return-options/;

http://www.nasaspaceflight.com/2014/01/golden-spikerecruit-draper-landing-sites/.

\section{JEGYZETEK}

1 A kézirat lezárva 2015. február 15. 